УДК 347.454.5

DOI https://doi.org/10.32849/2663-5313/2020.2.09

Олена Сібільова,

аспірантка кафедри цивільного права № 1

Національного юридичного університету імені Ярослава Мудрого

\title{
ВІДПОВІДАЛЬНІСТЬ ЗА ПОРУШЕННЯ ДОГОВОРУ ПРО НАДАННЯ ІНФОРМАЦИЙНИХ ПОСЛУГ
}

Аргументовано актуальність дослідження питання про відповідальність за порушення договору про надання інформаційних послуг у контексті проведення модернізаиії иивільного законодавства Украйни. Встановлено, що за ЦК України презюмується вина особи, яка порушила зобов'язання з договору про надання інформаційних послуг. Особа, яка порушила зобов'язання з договору про надання інформачійних послуг без вини, може бути притягнута до відповідальності тільки в тому разі, якщо це передбачено договором про надання інформачійних послуг. Загальною підставою відповідальності за порушення договору про надання інформаиійних послуг є невиконання або неналежне виконання зобов'язання з договору про надання інформачійних послуг. Будь-які інші підстави відповідальності за порушення договору про надання інформачійних послуг можуть бути встановлені иим договором.

Доведено, що иивільним законодавством України визначено тільки форму відповідальності виконавия у разі порушення договору про надання послуг. Збитки, завдані замовнику - користувачу інформаиійних послуг невиконанням або неналежним виконанням договору про надання інформаиійних послуг за плату, підлягають відикодуванню виконавием у разі наявності його вини у повному обсязі, якщо інше не встановлено договором про надання інформащійних послуг.

Доведено, що спеиіальною формою иивільно-правової відповідальності за порушення договору про надання інформаційних послуг є сплата неустойки. Аргументовано, що відшкодування моральної шкоди за порушення договору про надання інформаиійних послуг допускається, якщо ие прямо передбачено договором.

Обгрунтовано, що у разі порушення замовником-користувачем інформачійних послуг свойх зобов'язань за договором щодо оплати за надані послуги до иих відносин можуть бути застосовані положення статті 625 ЦК України щодо відповідальності за порушення грошового зобов'язання, тобто допускається стягнення суми боргу з урахуванням встановленого індексу інфляиіӥ за весь час прострочення, а також три проченти річних від простроченої суми, якщо інший розмір прочентів не встановлений договором або законом.

Ключові слова: договір, інформаційні послуги, договірна відповідальність, підстави відповідальності, форма відповідальності.

Постановка проблеми. Договір про надання інформаційних послуг, спрямований на задоволення інформаційної потреби замовника, $є$ непойменованим договором у цивільному праві та належить до групи договорів про надання послуг. Відповідно, загальні положення Цивільного кодексу України від 16 січня 2003 р. про відповідальність за договором про надання послуг можуть бути застосовані й до договору про надання інформаційних послуг. При цьому необхідно зазначити, що стаття 906 ЦК України визначає лише відповідальність виконавця за порушення договору про надання послуг, про відповідальність замовника взагалі не йдеться.

Натепер в Україні відбувається процес модернізації цивільного законодавства (рекодифікації), тому дослідження підстав, форм цивільно-правової відповідальності за порушення зобов'язань, що випливають iз договорів про надання інформаційних послуг, викликає підвищений науковий інтерес. Н. Кузнєцова наголошує, що потребує грунтовної «інвентаризації» весь правовий матеріал, який забезпечує регламентацію приватноправових відносин, зокрема сучасні наукові дослідження у сфері цивільного права, сформована на базі застосування цивільного законодавства судова практика тощо. Інститут юридичної відповідальності (і цивільно-правова відповідальність не $є$ винятком) завжди виступав не тільки потужним засобом захисту суб'єктивних прав, але й певним «індикатором» ефективності впливу права на суспільні відносини $[1$, c. 112$]$.

Аналіз останніх досліджень і публікацій. Зобов'язальні інформаційні відносини вже досліджувалися у доктрині приватного права України, зокрема в наукових працях А. Кодинця [2], О. Кохановської [3], П. Люті- 
кової [4]. Проте питання цивільно-правової відповідальності за порушення договору про надання інформаційних послуг досліджувалося фрагментарно у контексті характеристики правових наслідків невиконання чи неналежного виконання зобов'язань, що випливають із договорів про надання інформаційних послуг.

Метою цього дослідження є визначення підстав та форм цивільно-правової відповідальності за порушення договору про надання інформаційних послуг та розробка пропозицій щодо застосування окремих форм відповідальності за порушення договору про надання інформаційних послуг.

Виклад основного матеріалу. Оскільки договір про надання інформаційних послуг $\epsilon$ непойменованим договором, будемо виходити з такого визначення цього договору: за договором про надання інформаційних послуг одна сторона (виконавець) зобов'язується за завданням другої сторони (замовника - користувача інформаційних послуг) надати інформаційні послуги, результати яких не охороняються як об'єкти права інтелектуальної власності, мають певний корисний ефект немайнового характеру для замовника - користувача інформаційних послуг, а замовник - користувач інформаційних послуг зобов'язується оплатити виконавцеві інформаційні послуги, якщо інше не встановлено договором [5, с. 73].

Загальновідомо, що порушення будьякого договірного зобов'язання тягне за собою можливість застосування заходів цивільно-правової відповідальності. У сучасній науці цивільного права досить повно сутність цивільно-правової відповідальності встановлено Б. Карнаухом, який зазначає, що цивільно-правова відповідальність має три рівні сутності, які разом постають як ієрархія функціональних ідей, втілених у цьому інституті. На першому, найбільш прагматичному рівні своєї сутності цивільно-правова відповідальність - це механізм перерозподілу втрат: за допомогою цивільно-правової відповідальності втрати однієї особи переносяться (перерозподіляються) на рахунок іншої. Сутність другого рівня полягає в тому, що цивільна відповідальність є мірою відплати, оскільки в результаті перерозподілу відповідальності відбувається покладання нееквівалентного майнового позбавлення на сторону, яка порушила суб'єктивне право іншої. Саме через те, що відповідальність $є$ мірою відплати, вона й потребує вини як своєї передумови. На третьому, найвищому рівні своєї сутності цивільно-правова відповідальність постає як інституціоналізоване втілення загальноправових ідей: справедливості, визначеності, доцільності [6, с. 9].

Розглядаючи відповідальність за порушення договору про надання інформаційних послуг, насамперед постає питання про підстави такої відповідальності. Питання про підстави цивільно-правової відповідальності в доктрині приватного права є дискусійним, не визначено воно чітко й законодавцем. Н. Кузнєцова зазначає, що вчення про склад цивільного правопорушення як підстави цивільно-правової відповідальності набуло практично хрестоматійного характеру та увійшло у всі підручники з цивільного права [7, с. 345]. Також у юридичній літературі наголошується, що в сучасних умовах склад правопорушення перестає бути не тільки єдиною, але й навіть загальною підставою відповідальності, переміщуючись на роль лише однієї з таких підстав. Тому в загальних положеннях ЦК доцільно закріпити диференційований підхід до підстав цивільноправової відповідальності з тим, щоб відповідальність пов'язувалася не тільки і не стільки зі складом цивільного правопорушення, але й 3 іншими обставинами, передбаченими договором або законом [8, с. 169].

У контексті визначення підстави цивільно-правової відповідальності варто зазначити, що Г. Матвєєв вказував: «Без вини немає відповідальності». Навряд чи є інша теза, яка б так часто повторювалася в правовій літературі. I водночас навряд чи знайдеться в юриспруденції таке поняття, юридичний зміст якого так неоднаково трактувався б різними представниками правової науки та практики» [9, с. 156]. Саме такий підхід закладено і в ЦК України. Стаття 614 ЦК України має назву «Вина як підстава відповідальності за порушення зобов'язання». Відповідно до частин 1-2 ст. 614 ЦК України особа, яка порушила зобов'язання, несе відповідальність за наявності її вини (умислу або необережності), якщо інше не встановлено договором або законом. Особа є невинуватою, якщо вона доведе, що вжила всіх залежних від неї заходів щодо належного виконання зобов'язання. Відсутність своєї вини доводить особа, яка порушила зобов’язання.

Отже, за ЦК України презюмується вина особи, яка порушила зобов'язання з договору про надання інформаційних послуг. Особа, яка порушила зобов'язання 3 договору про надання інформаційних послуг без вини, може бути притягнута до відповідальності тільки в тому разі, якщо це передбачено договором про надання інформаційних послуг. Загальною підставою відповідальності за порушення договору про надання інформа- 
ційних послуг є невиконання або неналежне виконання зобов'язання, що випливає з договору про надання інформаційних послуг Будь-які інші підстави відповідальності за порушення договору про надання інформаційних послуг можуть бути встановлені цим договором

Відповідно до ст. 611 ЦК України в разі порушення зобов'язання настають правові наслідки, встановлені договором або законом, зокрема: 1) припинення зобов'язання внаслідок односторонньої відмови від зобов'язання, якщо це встановлено договором або законом, або розірвання договору; 2) зміна умов зобов'язання; 3) сплата неустойки; 4) відшкодування збитків та моральної шкоди.

У цьому контексті С. Бервено зазначає, що у разі порушення договірного зобов'язання до порушника можуть застосовуватися як міри цивільно-правової відповідальності, так й інші правові наслідки. Але у будь-якому разі серед цих правових наслідків центральне місце посідає цивільна відповідальність [10, с. 197]. На думку Є. Богданова, одним із центральних пунктів будь-якого договору $€$ відповідальність сторін за невиконання або неналежне виконання своїх договірних зобов'язань. Якби в договорі або у законодавстві відповідальність сторін не передбачалася, більшість договорів ніколи так і не були б виконані. Відповідальність, отже, відіграе роль стимулятора під час виконання договору [11, с. 72-73].

Інститут цивільно-правової відповідальності спрямований на реалізацію компенсаційної функції цивільного права, при цьому й сама цивільно-правова відповідальність виконує компенсаційну функцію. В. Примак справедливо відзначає, що компенсаційна функція характеризує суть і основний зміст цивільно-правової відповідальності як правового засобу, що покликаний ефективно поновити (у розумінні якомога повного відновлення становища, в якому мали б знаходитися сторони за відсутності правопорушення) порушені цивільні правовідносини та суб'єктивні цивільні права кредитора через перенесення у майнову сферу боржника негативних наслідків вчиненого ним правопорушення та відшкодування за рахунок зобов'язаної особи майнових чи моральних (немайнових) втрат кредитора (потерпілого) [12, с. 182].

Встановлення форм цивільно-правової відповідальності за порушення договору про надання інформаційних послуг має велике значення для правозастосовної діяльності. Форма цивільно-правової відповідальності розглядається правниками як засіб вираження додаткових майнових обтяжень, що покладаються на правопорушника [13, с. 370]. При цьому зауважується, що за домовленістю сторін у договорі може встановлюватися відповідальність за дії або бездіяльність, які у чинному законодавстві правопорушеннями не вважаються, або передбачатися інша форма відповідальності, ніж та, що закріплена у законі за певне правопорушення [13, с. 367-368].

Я. Шевченко зазначала, що універсальною мірою майнової відповідальності в цивільному праві є стягнення збитків, хоча, безсумнівно, є й інші санкції, які також слугують виразу відповідальності як правового інституту. Серед них можна назвати відшкодування шкоди в натурі (надання речі того ж роду і якості, виправлення пошкодженої речі), неустойку, пеню, штраф, стягнення майна у дохід держави та інші [14, с. 29].

Згідно з ч. 1 ст. 906 ЦК України збитки, завдані замовнику невиконанням або неналежним виконанням договору про надання послуг за плату, підлягають відшкодуванню виконавцем у разі наявності його вини у повному обсязі, якщо інше не встановлено договором. Виконавець, який порушив договір про надання послуг за плату під час здійснення ним підприємницької діяльності, відповідає за це порушення, якщо не доведе, що належне виконання виявилося неможливим внаслідок непереборної сили, якщо інше не встановлено договором або законом.

Враховуючи, що договір про надання інформаційних послуг належить до групи договорів про надання послуг, можна зробити висновок, що збитки, завдані замовнику - користувачу інформаційних послуг невиконанням або неналежним виконанням договору про надання інформаційних послуг за плату, підлягають відшкодуванню виконавцем у разі наявності його вини у повному обсязі, якщо інше не встановлено договором про надання інформаційних послуг.

Стаття 624 ЦК України передбачає: якщо за порушення зобов'язання встановлено неустойку, то вона підлягає стягненню у повному розмірі, незалежно від відшкодування збитків. Договором може бути встановлено обов'язок відшкодувати збитки лише в тій частині, в якій вони не покриті неустойкою. Договором може бути встановлено стягнення неустойки без права на відшкодування збитків або можливість за вибором кредитора стягнення неустойки чи відшкодування збитків.

За порушення договору про надання інформаційних послуг може бути стягнуто неустойку, якщо це безпосередньо передбачено договором. Так, в ухвалі Вищого 
спеціалізованого суду України з розгляду цивільних і кримінальних справ від 10 жовтня 2017 р. у справі № 592/3690/16-ц зазначається, що вирішуючи спір, суди виходили з того, що оскільки позивачем були виконані умови укладеного між сторонами договору про надання інформаційних послуг і надано відповідачу перелік об’єктів нерухомості, які пропонувались на ринку нерухомості і відповідали загальним вимогам заявника, а відповідач відповідно до договору купівлі-продажу придбав об'єкт нерухомості, який був зазначений у цьому переліку, але не оплатив надані йому послуги, тому заявлені вимоги про стягнення на користь позивача оплати та неустойки, встановлені умовами договору, підлягають задоволенню. Відповідно до пунктів 10.2, 10.3 укладеного між сторонами договору від 2 вересня 2015 року передбачена виплата неустойки в сумі 5000 грн у разі, якщо замовником було укладено договір переходу права власності на об'єкт з покупцем, який був наданий виконавцем, не була здійснена оплата за надані послуги в передбаченому розмірі та в передбачений договором строк [15].

Розглядаючи спори про відповідальність сторін за порушення договору про надання інформаційних послуг, суди входять з того, що зобов'язання замовника зі сплати послуг виконавця $\in$ грошовим зобов'язанням. Видається, що такий підхід є правильним. Зокрема, Касаційний цивільний суд Верховного Суду в своїй постанові від 28 лютого 2018 р. у судовій справі № 643/15598/15-ц зазначив, що судами першої та апеляційної інстанцій встановлено, що 3 червня 2015 р. між ФОП ОСОБА_4 (виконавець) та ОСОБА_5 (замовник) укладено договір про надання інформаційних послуг 3 приводу пошуку нерухомості (квартири) для придбання у власність. Відповідно до пунктів 1.1, 3.4, 4.3, 7 договору про надання інформаційних послуг сторони домовились, що ОСОБА_5 сплачує виконавцю винагороду в розмірі 5\% від вартості об'єкта нерухомого майна, що становить 15750 грн, і у разі порушення строків оплати замовник сплачує штраф у розмірі 30\% від вартості послуг. 3 червня 2015 р. між ОСОБА_5 та продавцем квартири укладено договір про аванс та оплату послуг, відповідно до умов якого сторони договору домовились до 30 червня 2015 р. укласти договір купівлі-продажу квартири. Встановлені обставини свідчать про виконання виконавцем послуг своїх обов'язків, передбачених пунктами 1.1, 2.1.1, 2.1.2, 2.1.3 договору про надання інформаційних послуг. 17 червня 2015 р. ОСОБА_5 придбала у власність квартиру та зареєструвала іï на своє ім'я Згідно з пунктом 3.2 договору про надання інформаційних послуг оплата послуг виконавця здійснюється в день укладення авансового договору або в день укладення договору купівлі-продажу, але до моменту його підписання. У разі, якщо вказані договори укладені не будуть, послуги виконавця не оплачуються. Однак ОСОБА 5 про придбання квартири ФОП ОСОБА_4 не повідомила, оплату послуг згідно з договором про надання послуг не здійснила. Згідно зі статтею 903 ЦК України, якщо договором передбачено надання послуг за плату, замовник зобов'язаний оплатити надану послугу в розмірі, в строки та в порядку, що встановлені договором. Якщо неможливість виконати договір виникла з вини замовника, він зобов'язаний виплатити виконавцеві плату в повному обсязі, якщо інше не встановлено договором або законом. Таким чином, правовідношення, в якому замовник зобов'язаний оплатити надану послугу в грошах, а виконавець має право вимагати від замовника відповідної оплати, тобто в якому передбачається передача грошей як предмета договору або сплата їх як ціни договору, є грошовим зобов'язанням. Саме до таких грошових зобов’язань належить укладений договір про надання послуг, оскільки він установлює ціну договору. Установивши, що виконавцем договору про надання послуг умови цього договору виконано та знайдено нерухоме майно (квартиру) з метою придбання, однак замовником умови договору виконані не були, оплати за надані послуги в установлений строк не здійснено, суди попередніх інстанцій дійшли обгрунтованого висновку про стягнення з відповідача на користь ФОП ОСОБА 4 заборгованості зі сплати послуг у розмірі 15750 грн та штрафу у розмірі 1725 грн [16].

Отже, до замовника - користувача інформаційних послуг, який не виконав чи неналежно виконав свої обов'язки за договором про надання інформаційних послуг, можуть бути застосовані положення ст. 625 ЦК України, що встановлюють відповідальність за порушення грошового зобов'язання.

Згідно 3 п. 4 ч. 1 ст. 611 ЦК України, в разі порушення зобов'язання настають правові наслідки, встановлені договором або законом, зокрема відшкодування збитків та моральної шкоди. Відповідно, можна зробити висновок, що відшкодування моральної шкоди однією зі сторін у разі порушення договору про надання інформаційних послуг можливе лише у випадку, якщо це передбачено безпосередньо договором про надання інформаційних послуг. 
В. Примак зазначає, що відшкодування майнової та моральної шкоди (пункти 8 і 9 частини 2 ст. 16 та статті 22 і 23 ЦК) становлять такі способи цивільно-правового захисту, котрі разом із функцією захисту (відновлення майнового стану, надання компенсації немайнових втрат) порушених цивільних прав здатні виконувати запобіжну функцію щодо можливого вчинення правопорушення. Водночас лише два названі способи здатні відновити фактичні майнові чи компенсувати у матеріальній формі немайнові (моральні) втрати кредитора (потерпілого). 3 цього випливає притаманна винятково цим правовим засобам компенсаційна функція [12, с. 33].

Отже, можливість відшкодування моральної шкоди за порушення договору про надання інформаційних послуг у разі визначення такої форми відповідальності в договорі спрямована на реалізацію превентивної та компенсаційної функцій цивільного права

\section{Висновки}

Таким чином, загальною підставою відповідальності за порушення договору про надання інформаційних послуг $є$ невиконання або неналежне виконання зобов'язання 3 договору про надання інформаційних послуг. Будь-які інші підстави відповідальності за порушення договору про надання інформаційних послуг можуть бути встановлені цим договором. Збитки, завдані замовнику - користувачу інформаційних послуг невиконанням або неналежним виконанням договору про надання інформаційних послуг за плату, підлягають відшкодуванню виконавцем у разі наявності його вини у повному обсязі, якщо інше не встановлено договором про надання інформаційних послуг. Договором про надання інформаційних послуг може бути передбачено стягнення неустойки, відшкодування моральної шкоди.

Зобов'язання замовника - користувача інформаційних послуг зі сплати послуг виконавця є грошовим зобов'язанням. У разі порушення замовником - користувачем інформаційних послуг своїх зобов'язань за договором щодо оплати за надані інформаційні послуги до цих відносин можуть бути застосовані положення статті 625 ЦК України щодо відповідальності за порушення грошового зобов’язання, тобто допускається стягнення суми боргу 3 урахуванням встановленого індексу інфляції за весь час прострочення, а також три проценти річних від простроченої суми, якщо інший розмір процентів не встановлений договором або законом.

Подальше дослідження відповідальності за порушення договору про надання інфор- маційних послуг сприятиме підвищенню ефективності застосування цивільного законодавства

\section{Список використаних джерел:}

1. Кузнєцова Н.С. Інститут цивільно-правової відповідальності у контексті рекодифікації цивільного права України. Модернізачія иивільноправової відповідальності. Матвєєвські цивілістичні читання : матеріали міжн. наук.-практ. конф. Київ, 18 жовт. 2019 р. / Р.А. Майданик, В.В. Цюра та ін. ; відп. ред. Р.А. Майданик. Київ, 2019. C. $112-114$.

2. Кодинець А.О. Цивільно-правове регулювання зобов'язальних інформаційних відносин: методологія, теорія, практика : дис. ... д-ра юрид. наук : 12.00.03. Київськ. нац. ун-т імені Тараса Шевченка. Київ, 2016. 470 с.

3. Кохановська О.В. Цивільно-правові проблеми інформаційних відносин в Україні : дис. ... д-ра юрид. наук : 12.00.03. Київськ. нац. ун-т імені Тараса Шевченка. Київ, 2006. 531 с.

4. Лютікова П. Поняття та види договорів на надання інформаційних послуг. Право Украйни. 2008. № 7. C. 91-94.

5. Сібільова О. Поняття договору про надання інформаційних послуг. Підприємниитво, господарство і право. 2019. № 11. С. 70-74.

6. Карнаух Б.П. Вина як умова цивільноправової відповідальності : автореф. дис. ... канд. юрид. наук : 12.00.03. Нац. ун-т «Юридична академія України імені Ярослава Мудрого». Харків, 2013. $21 \mathrm{c}$.

7. Правова доктрина України : у 5 т. Т. 3: Доктрина приватного права України / Н.С. Кузнєцова, Є.О. Харитонов, Р.А. Майданик та ін. ; за заг. ред. Н.С. Кузнєцової. Харків : Право, 2013. 760 с.

8. Цивільний і Господарський кодекси: 20042014 рр. : монографія / I.В. Спасибо-Фатєєва, В.І. Крат, Ю.В. Мица та ін. ; за заг. ред. І.В. Спасибо-Фатєєвої. Харків : Право, 2014. 204 с.

9. Матвєєв Г.К. Вибране / упоряд. В.І. Кисіль. Київ : Україна, 2008. 600 с

10. Бервено С.М. Проблеми договірного права України : монографія. Київ : Юрінком Інтер, 2006. 392 c.

11. Богданов Е.В. Договор в сфере предпринимательства. Харьков : Фирма «Консум», 1997. $112 \mathrm{c}$.

12. Примак В.Д. Цивільно-правова відповідальність юридичних осіб : дис.... канд. юрид. наук : 12.00.03. Ін-т держави і права ім. В.М. Корецького. Київ, 2005. 209 с.

13. Цивільне право : підручник : у 2 т. / В.І. Борисова (кер. авт. кол.), Л.М. Баранова, Т.І. Бєгова та ін. ; за ред. В.І. Борисової, І.В. Спасибо-Фатєєвої, В.Л. Яроцького. Харків : Право, 2011. T. $2.816 \mathrm{c}$.

14. Повышение роли гражданско-правовой ответственности в охране прав и интересов граждан и организаций / отв. ред.: Собчак А.А., Шевченко Я.Н. Киев : Наукова думка, 1988. 264 с. 
15. Ухвала Вищого спеціалізованого суду України з розгляду цивільних і кримінальних справ від 10 жовтня 2017 року, судова справа №592/3690/16-ц. URL:http://reyestr.court.gov.ua/ Review/69578882 (дата звернення: 15.01.2020).
16. Постанова Касаційного цивільного суду Верховного Суду від 28 лютого 2018 року, судова справа № 643/15598/15-ц. URL http://reyestr.court.gov.ua/Review/72641511 (дата звернення: 20.01.2020).

The author has argued the relevance of the research in regard to the issue of liability for the violation of a contract on the provision of information services in the context of the modernization of civil legislation of Ukraine. It has been established that the guilt of a person who violated the obligations under the contract on the provision of information services is presumed under the Civil Code of Ukraine. A person, who has violated obligations under the contract on providing information services without fault, can be brought to liability only in case, if it is stipulated by the contract for providing information services. Failure to perform or improper performance of obligations under the contract for providing information services are the general grounds for liability for the violation of the contract for providing information services. Any other grounds of liability for the violation of the contract for providing information services may be established by this contract.

It has been proved that civil legislation of Ukraine only determines the form of liability of the contractor in case of the violation of the contract for providing services. Losses caused to the customer of information services by non-performance or improper performance of the contract for providing information services for a fee, shall be fully compensated by the contractor, in case of his fault, unless otherwise stipulated by the contract for providing information services.

The author has proved that a special form of civil liability for violating the contract on the provision of information services is the payment of forfeit. It has been argued that redress for the non-pecuniary damage for violating the contract for the provision of information services is allowed, if it is expressly provided by the contract.

It has been substantiated that in case of the violation of the obligations by the customer of information services under the contract for the payment of provided services, the provisions of the Art. 625 of the Civil Code of Ukraine may be applied to these relationships regarding the liability for the violation of monetary obligations. In this case the amount of debt may be recovered taking into account the established inflation rate for the entire period of delay, as well as three percent per annum of the overdue amount, unless another rate of interest is established by the contract or by the law.

Key words: contract, information services, contractual liability, grounds for liability, form of liability. 